\title{
Analisis Nilai Tambah Agroindustri Barang Jadi Karet di Provinsi Lampung
}

\author{
Analysis of Agro-Industry Value Added of Rubber Finished Goods in Lampung Province \\ Sri Hidayati ${ }^{\star}$, Erdi Suroso1, Teguh Setiawan', Joshua Septiyan'1, Agus Kurniawan² \\ 1Jurusan Teknologi Hasil Pertanian, Fakultas Pertanian Universitas Lampung, Jl. Sumantri Brojonegoro No. 1 Bandar \\ Lampung, 35145, Indonesia \\ 2Jurusan Akuntansi Syariah, Fakultas Ekonomi dan Bisnis Islam, Universitas Islam Negeri Raden Intan Lampung, Jl. Endro \\ Suratmin Sukarame Bandar Lampung, 35131, Indonesia \\ *E-mail: srihidayati.unila@gmail.com
}

Diterima: 5 November 2019; Disetujui: 10 Mei 2020

\begin{abstract}
ABSTRAK
Lampung merupakan salah satu sentra perkebunan karet yang belum banyak memiliki pabrik pengolahan barang jadi karet. Harga karet yang cenderung menurun menyebabkan penurunan pendapatan petani karet. Upaya untuk mendapatkan added value karet adalah dengan mengolah karet menjadi produk barang jadi karet. Beberapa jenis agroindustri barang jadi karet yang tidak memerlukan teknologi yang tinggi seperti kasur busa, sarung tangan, selang kateter, dan dot dapat diaplikasikan di Lampung. Penelitian bertujuan untuk menentukan jenis industri barang jadi karet yang potensial di Provinsi Lampung dan lokasi yang cocok untuk pendirian agroindustri barang jadi karet. Penelitian dilakukan dengan menggunakan metode survei dan wawancara secara mendalam kepada pakar karet dan industri serta data sekunder dari literatur, artikel, jurnal dan data statistik. Pemilihan produk potensial dan lokasi usaha dilakukan dengan menggunakan metode Bayes dan menghitung nilai tambah dari produk terpilih dengan menggunakan metode Hayami. Berdasarkan hasil perhitungan dengan menggunakan metode Bayes maka pemilihan komoditas unggulan untuk di Provinsi Lampung adalah kasur busa dengan nilai Metode Bayes sebesar 4,048 dan lokasi terpilih adalah kabupaten Lampung Utara dengan nilai 3,875. Berdasarkan metode Hayami maka nilai tambah yang dihasilkan jika lateks pekat diolah menjadi kasur busa adalah Rp. 8549,56/kg lateks pekat dengan nilai rasio nilai tambah adalah sebesar $18,45 \%$.
\end{abstract}

Kata kunci: lateks; karet; metode Bayes; metode Hayami

\section{ABSTRACT}

Lampung is one of the centers of rubber plantations that do not yet have many factories processing rubber goods. Rubber prices that tend to decline cause a decrease in rubber farmers' income. Efforts to get rubber added value is by processing rubber into rubber finished goods. Several types of agro-industry of rubber finished goods that do not require high technology such as foam mattresses, gloves, catheter hoses, and teats can be applied in Lampung. The research aims to determine the type of potential rubber finished goods industry in Lampung province and a suitable location for the establishment of rubber finished goods agro-industry. The study was conducted using survey methods and in-depth interviews with rubber and industry experts as well as secondary data from literature, articles, journals and statistical data. The selection of potential products and business locations is done by using the Bayes method and calculating the added value of the selected products using the Hayami method. Based on the calculation using the Bayes method, the selection of leading commodities for Lampung province is a foam mattress with a Bayes Method value of 4.048 and the selected location is the North Lampung district with a value of 3.875. Based on the Hayami method, the added value generated if concentrated latex is processed into a foam mattress is Rp. 8549.56 / kg concentrated latex with a value-added ratio of $18.45 \%$.

Keywords: latex; rubber; Bayes method; Hayami method

\section{PENDAHULUAN}

Lampung merupakan 10 daerah penghasil karet terbesar di Indonesia. Produksi karet Lampung tahun 2018 mencapai 192.133 ton dengan luas areal 172.371 hektar (www.bps.go.id) dengan luas areal 156.878 hektar dengan kabupaten penghasil karet terbanyak adalah Way kanan, Lampung Utara, Tulang Bawang, Mesuji dan Tulang Bawang Barat (lampung.bps.go.id). Harga getah karet mengalami penurunan dari harga Rp7.500/kg menjadi Rp6.500/kg (lampung.antaranews.com). Rendahnya harga jual bahan olah karet di tingkat petani yang disebabkan oleh lemahnya posisi petani dalam hal tawar menawar (Hutagalung et al. 2017). Selama ini, petani karet di Lampung hanya menjual karet dalam bentuk lump dengan mutu yang rendah sehingga harga jual menjadi rendah dan dijual ke pabrik pengolahan karet crumb rubber. Salah satu upaya untuk meningkatkan pendapatan petani adalah dengan mengolah lateks menjadi produk yang memiliki nilai jual dengan menggunakan teknologi yang sederhana. Pengembangan agroindustri olahan karet akan meningkatkan produktivitas secara ekonomi dan dapat menstimulasi produksi pertanian primer sehingga menghasilkan insentif dari sisi permintaan dan penawaran (Priyarsono, 2011). Indonesia masih bertindak sebagai pemasok bahan baku karet untuk negara penghasil karet jadi. Indonesia memiliki peluang potensi pasar dalam negeri yang besar yaitu sebesar $60 \%$ meskipun skala usaha UKM saja Konsumsi barang jadi karet di Indonesia hanya $16,74 \%$ dari total produksi nasional (Fauzi, 2013). Dengan mengalihkan penjualan dalam bentuk lump 
menjadi lateks pekat, diharapkan industri pengolahan karet dapat memanfaatkan lateks menjadi produk barang jadi karet yang industrinya belum terdapat di Lampung.

Pengolahan lateks pekat bertujuan untuk mendapatkan lateks pekat dengan kadang karet kering menjadi 60-64\% (Marsongko, 2013). Bahan baku lateks pekat dapat dimanfaatkan sebagai bahan baku karet busa, kondom, sarung tangan, selang kateter, alat kesehatan, balon perlak, karpet, pelampung dan lem (Maspanger, 2007). Untuk mengetahui jenis industri yang cocok dengan menggunakan bahan baku lateks pekat maka dilakukan analisis pemilihan produk potensial yang dapat dikembangkan di Provinsi Lampung dan pemilihan lokasi industri mengingat penghasil karet di Lampung tersebar di beberapa kabupaten. Metode yang digunakan adalah metode Bayes. Metode Bayes dilakukan dengan penilaian yang melibatkan pakar. Hasil analisis produk potensial yang terpilih berdasarkan metode Bayes kemudian dianalisis nilai tambahnya dengan menggunakan metode Hayami. Metode nilai tambah adalah indikator penting kegiatan ekonomi suatu usaha yang mencerminkan kemampuan ekonominya (Căruntu \& Lăpăduşi, 2012; Sutopo et al. 2013; Sutopo et al. 2014; Kusuma et al. 2016). Terdapat sejumlah penelitian yang telah dilakukan untuk menghitung nilai tambah, diantaranya analisis input-ouput (Putri et al. 2015; Wijaya et al. 2014); analisis Economic Value Added (Prabowo, 2004; Mardiyanto, 2013); dan Metode Hayami (Febriyanti et al. 2017; Safri, 2013). Metode Hayami digunakan untuk menghitung nilai tambah. Purwaningsih (2015) menyatakan bahwa metode ini dapat digunakan untuk mengetahui nilai output, produktivitas, sumbangan input lain, keuntungan perusahaan, dan tenaga kerja (Hayami et al.1987; Firdaus, 2014; Yuliana, 2007; Febriyanti et al. 2017). Menurut Hayami et al (1987), nilai tambah yaitu tambahan nilai komoditas oleh adanya perlakuan yang diberikan suatu komoditas yang bersangkutan. Besarnya nilai tambah yang diperoleh berdasarkan kriteria nilai tambah (Febriyanti et al. 2017), yakni: (a) jika nilai tambah (NT) >0, artinya aktivitas pengolahan memberikan nilai tambah; dan (b) jika nilai tambah (NT) < 0 , artinya aktivitas pengolahan tidak memberikan nilai tambah. Tujuan peneltian ini adalah menentukan jenis industri barang jadi karet yang potensial di Provinsi Lampung dan lokasi yang cocok untuk pendirian agroindustri barang jadi karet menggunakan metode Bayes dan menghitung nilai tambah dari produk terpilih dengan menggunakan metode Hayami.

\section{METODOLOGI PENELITIAN}

Penelitian dilakukan dengan menggunakan metode survei dan wawancara secara mendalam kepada pakar karet dan industri serta data sekunder dari literatur, artikel, jurnal dan data statistik. Pakar yang terlibat adalah dari Dinas Perindustrian, Dinas Perdagangan, BAPPEDA Provinsi Lampung dan akademisi. Pemilihan produk potensial dan lokasi usaha dilakukan dengan menggunakan metode bayes. Metode Bayes dimanfaatkan untuk mendapatkan urutan prioritas alternatif keputusan dengan kriteria jamak (Marimin, 2007). Perbedaan nilai antara kriteria tergantung kepada kepakaran dari penilai. Penilaian metode Bayes dilakukan secara kuantifikasi pada kejadian dan dinyatakan dalam bilangan antara 0 dan 1 . Bobot Bayes ditetapkan berdasarkan tingkat kepercayaan, keyakinan, pengalaman termasuk latar belakang pengambilan keputusan (Rangkuti, 2011). Persamaan Bayes sebagai berikut:
Total nilai $i_{i}=\sum_{j=1}^{m}$ Nilai $_{i j}\left(\right.$ Krit $\left._{j}\right)$

Dimana:

Total nilai $\mathrm{i}=$ Total nilai akhir dari alternatif ke-i

Nilai $i_{j} \quad=$ Nilai dari alternatif ke-l pada kriteria ke-j

Krit $\mathrm{j}=$ Tingkat kepentingan (bobot) kriteria ke-j

I $=1,2,3, \ldots . n ; n=$ jumlah alternative

$\mathrm{J}=1,2,3, \ldots \mathrm{n} ; \mathrm{n}=$ jumlah kriteria

Sementara itu, prosedur perhitungan nilai tambah dengan memakai metode Hayami ditampilkan pada Tabel 1.

Tabel 1. Perhitungan nilai tambah berdasarkan metode Hayami

\begin{tabular}{cll}
\hline No & $\begin{array}{l}\text { Keluaran (output), Masukan } \\
\text { (Input), dan Harga }\end{array}$ & Nilai \\
\hline 1 & Output/produk total & $\mathrm{A}$ \\
2 & Input bahan baku & $\mathrm{B}$ \\
3 & Input tenaga kerja & $\mathrm{C}$ \\
4 & Faktor konversi & $\mathrm{D}=\mathrm{A} / \mathrm{B}$ \\
5 & Koefisien tenaga kerja & $\mathrm{E}=\mathrm{C} / \mathrm{B}$ \\
6 & Harga output & $\mathrm{F}$ \\
7 & Upah rata-rata tenaga kerja & $\mathrm{G}$ \\
\hline
\end{tabular}

\begin{tabular}{|c|c|c|}
\hline & \multicolumn{2}{|l|}{ Pendapatan dan Keuntungan } \\
\hline 8 & Harga input bahan baku & $\mathrm{H}$ \\
\hline 9 & Sumbangan input lain & I \\
\hline 10 & Nilai output & $J=D F$ \\
\hline \multirow[t]{2}{*}{11} & a. Nilai tambah & $\mathrm{K}=\mathrm{J}-\mathrm{I}-\mathrm{H}$ \\
\hline & b. Rasio nilai tambah & $L(\%)=(K / J) 100 \%$ \\
\hline \multirow[t]{2}{*}{12} & a. Imbalan tenaga kerja & $M=E G$ \\
\hline & b. Bagian tenaga kerja & $N(\%)=M / K 100 \%$ \\
\hline \multirow[t]{3}{*}{13} & a. Keuntungan & $\mathrm{O}=\mathrm{K}-\mathrm{M}$ \\
\hline & b. Tingkat keuntungan & $P(\%)=(O / J) 100 \%$ \\
\hline & $\begin{array}{l}\text { Balas jasa untuk pemilik } \\
\text { faktor-faktor produksi }\end{array}$ & \\
\hline \multirow[t]{4}{*}{14} & Laba & $\mathrm{Q}=\mathrm{J}-\mathrm{H}$ \\
\hline & a. Pendapatan tenaga kerja & $R(\%)=M / Q \quad 100 \%$ \\
\hline & b. Sumbangan input lain & $S(\%)=I / Q \quad 100 \%$ \\
\hline & c. Keuntungan usaha & $\mathrm{T}(\%)=(\mathrm{O} / \mathrm{Q}) 100 \%$ \\
\hline
\end{tabular}

Sumber: Hayami et al. 1987

\section{HASIL DAN PEMBAHASAN}

\section{Pemilihan Produk Potensial}

Pemilihan produk karet olahan potensial berdasarkan pedoman pada pohon industri karet dimana lateks pekat dapat diolah menjadi sarung tangan, kasur busa, selang stetoskop dan dot bayi. Ada lima kriteria yang dipertimbangkan dalam menentukan produk potensial karet olahan berbahan baku lateks pekat yaitu potensi pasar, kondisi bahan baku, analisis nilai tambah produk, teknologi proses dan dampak terhadap lingkungan. Berdasarkan penilaian dengan menggunakan Metode Bayes maka terpilih kasur busa dengan nilai Metode Bayes sebesar 4,048 diikuti sarung tangan karet $(3,916)$, selang stetoskop $(2,392)$ dan dot bayi $(1,256)$ (Tabel 2). 
Tabel 2. Hasil Penilai Metode Bayes Terhadap Pemilihan Produk Olahan Karet Jadi Potensial

\begin{tabular}{lccccc}
\hline \multicolumn{1}{c}{ Kriteria } & Bobot & $\begin{array}{c}\text { Sarung } \\
\text { karet }\end{array}$ & $\begin{array}{c}\text { Kasur } \\
\text { busa }\end{array}$ & $\begin{array}{c}\text { Selang } \\
\text { stetoskop }\end{array}$ & $\begin{array}{c}\text { Dot } \\
\text { bayi }\end{array}$ \\
\hline $\begin{array}{l}\text { Potensi } \\
\text { pasar }\end{array}$ & 0,48 & 4,4 & 4,2 & 2,2 & 2,8 \\
\hline $\begin{array}{l}\text { Kondisi } \\
\text { bahan baku }\end{array}$ & 0,20 & 3,6 & 4,2 & 2,2 & 1,4 \\
\hline $\begin{array}{l}\text { Nilai } \\
\text { tambah } \\
\text { produk }\end{array}$ & 0,20 & 3,6 & 4 & 2,8 & 3,2 \\
\hline $\begin{array}{l}\text { Penguasaa } \\
\text { n teknologi }\end{array}$ & 0,07 & 3,2 & 3,6 & 2,8 & 2,8 \\
\hline $\begin{array}{l}\text { Dampak } \\
\text { terhadap } \\
\text { lingkungan }\end{array}$ & 0,05 & 2,8 & 2,8 & 2,8 & 2,8 \\
\hline Nilai Bayes & & 3,916 & 4,048 & 2,392 & 1,256 \\
\hline
\end{tabular}

Karet busa merupakan salah satu bahan yang dapat digunakan sebagai kasur (Pujiastuti, 2007). Kasur busa memiliki keunggulan, yaitu lebih sejuk bila digunakan karena adanya pori pori yang terjebak didalam pori pori kasur. Selain itu, karet busa juga dapat dimanfaatkan sebagai peredam suara di studio, pelapis dinding. Karet jenis ini juga memiliki sifat yang lebih stabil dalam menahan getaran sehingga cocok digunakan untuk sandaran kursi maupun jok kendaraan bermotor.

Potensi pasar diperlukan karena dapat membantu perusahaan untuk menetapkan besaran produksi, penetapan harga dan menganalisis perilaku konsumen (Suliyanto, 2010). Kasur busa bersaing dengan kasur busa sintetis sehingga harganya relatif lebih mahal. Namun demikian, karet busa sintetis mengandung isosianat yang bersifat karsinogenik sehingga berdampak buruk terhadap kesehatan manusia jika mengenai kulit secara terus menerus (Nurhayati, 2012). Diharapkan dengan meningkatnya kesadaran akan kesehatan, penggunaan karet busa alam akan meningkat karena karet busa alam memiliki beberapa keunggulan yaitu higienis, bebas dari segala macam kutu dan serangga dan tidak berdebu seperti kapuk. Tungau debu (Dermatophagoides pteronyssinus) merupakan tungau penyebab alergen hirup dan menyebabkan asma bronchial (Yudopranoto, 2006). Kriteria kedua yang terpenting adalah kondisi bahan baku. Ibrahim (2009) menyatakan bahwa kestabilan kontinuitas bahan baku sangat menunjang kemajuan industri dalam berproduksi karena mengingat karet merupakan produk pertanian yang bersifat perishable dan kamba. Bahan baku yang diperlukan untuk industri karet jadi mengalami peningkatan produktifitas (Gambar 1). Bentuk usaha pengelolaan bahan baku berupa kemitraan yang dilakukan industri dengan memberi pelatihan kepada petani untuk meningkatkan mutu lateks yang baik dan harga yang memadai.

Barang jadi karet pada umumnya tidak memerlukan teknologi yang tinggi sehingga mudah untuk dikembangkan (Suparto dan Syamsu, 2008). Proses pembuatan kasur busa meliputi penyiapan bahan baku, penyiapan dispersi dan larutan bahan kimia kompon, penyediaan kompon, pembentukan barang jadi, pengeringan dan penyempurnaan (Badan Penelitian Teknologi Karet Bogor, 2002).

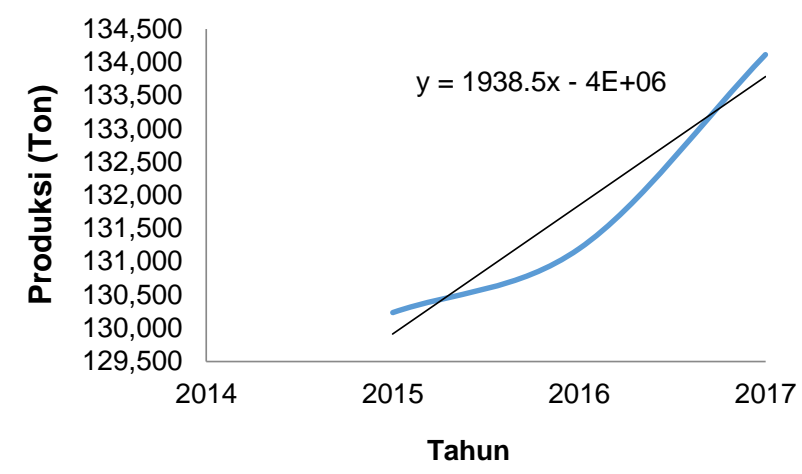

Gambar 1. Trend grafik peningkatan produksi karet di Provinsi Lampung tahun 2015-2017 (Direktorat Jendral Perkebunan, 2017).

\section{Penentuan Lokasi Agroindustri}

Terdapat 4 kandidat lokasi alternatif yang dipilih yaitu Kabupaten Way Kanan, Lampung Utara, Tulang Bawang dan Mesuji. Keempat kandidat lokasi ini dipilih berdasarkan produktifitas dan luas areal terbanyak di Lampung.

Menurut Ibrahim (2009), terdapat beberapa hal yang menjadi pertimbangan untuk menentukan lokasi suatu industri yaitu dukungan pemerintah, sarana transportasi, dukungan masyarakat, potensi bahan baku, kemudahan suplai bahan baku, ketersediaan tenaga kerja, dan kemudahan akses dengan pasar. Berdasarkan analisa menggunakan Metode Bayes, diperoleh hasil bahwa kabupaten Lampung Utara terpilih karena memiliki skor nilai tertinggi yaitu 3,875 (Tabel 3).

Tabel 3. Pemilihan Lokasi untuk Pendirian Agroindustri Karet Busa Berdasarkan Metode Bayes

\begin{tabular}{lccccc}
\hline \multirow{1}{*}{ Kriteria } & Bobot & \multicolumn{5}{c}{ Nilai Alternatif Produk } \\
\cline { 3 - 6 } & $\begin{array}{l}\text { Way } \\
\text { kanan }\end{array}$ & $\begin{array}{c}\text { Lampung } \\
\text { utara }\end{array}$ & $\begin{array}{c}\text { Tulang } \\
\text { bawang }\end{array}$ & Mesuji \\
\hline $\begin{array}{l}\text { Aksesibilitas } \\
\text { ke pasar }\end{array}$ & 0,23 & 3,2 & 3,8 & 2,6 & 2,2 \\
\hline $\begin{array}{l}\text { Ketersediaan } \\
\text { transportasi }\end{array}$ & 0,23 & 4 & 4,2 & 3,6 & 3,2 \\
\hline $\begin{array}{l}\text { Dukungan } \\
\text { pemerintah }\end{array}$ & 0,21 & 4,6 & 4,6 & 4,2 & 4,2 \\
\hline $\begin{array}{l}\text { Dukungan } \\
\text { masyarakat }\end{array}$ & 0,17 & 4,2 & 4,2 & 4 & 4 \\
\hline $\begin{array}{l}\text { Potensi } \\
\text { bahan baku }\end{array}$ & 0,08 & 4,2 & 4,8 & 3,8 & 3,4 \\
\hline $\begin{array}{l}\text { Ketersediaan } \\
\text { tenaga kerja }\end{array}$ & 0,08 & 4 & 4,4 & 4 & 3,8 \\
\hline Nilai Bayes & & 3,656 & 3,872 & 3,308 & 2,602 \\
\hline
\end{tabular}

Kabupaten Lampung Utara yang hanya berjarak $132 \mathrm{~km}$ dari ibu kota Provinsi, memiliki kemudahan akses untuk ke pasar karena memiliki jalan yang dilalui oleh Lintas Sumatra serta dekat dengan ibukota Lampung Selatan (Palembang). Hal ini diharapkan memberi kemudahan untuk akses menuju pasar, baik pasar ke daerah Jawa maupun wilayah Sumatera.

Dukungan Pemerintah Kabupaten Lampung Utara dituangkan di dalam Rencana Pembangunan Jangka Menengah Daerah (RPJMD) tahun 2015-2019. Pemerintah Daerah memberi dukungan permodalan dan pembinaan teknis terhadap pelaku Usaha Mikro Kecil dan Menengah (UMKM) serta peningkatan daya saing produk UMKM. Dukungan masyarakat yang cukup tinggi dapat dilihat dari jumlah industri yang terdapat di Kabupaten Lampung Utara, yang dapat menyerap tenaga kerja sebanyak 3.882 jiwa 
(Badan Perencanaan Pembangunan Daerah Kabupaten Lampung Utara, 2016). Persediaan bahan baku di Kabupaten Lampung Utara terpenuhi karena berdasarkan data Dinas Kehutanan dan Perkebunan Kabupaten Lampung Utara tahun 2015 luas area perkebunan mencapai 35.288 ha dengan produktivitas sebesar 16.612 ton dan terus mengalami peningkatan (Gambar 2).

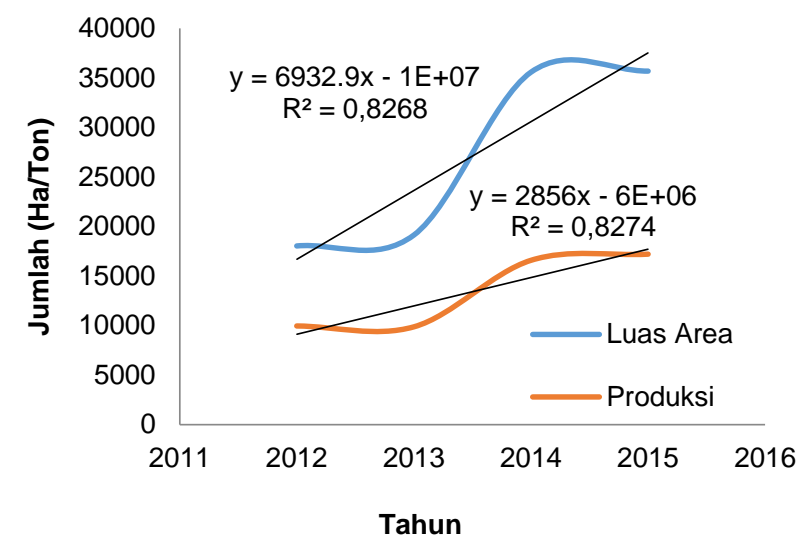

Gambar 2. Luas lahan dan produksi karet kabupaten lampung utara (BPPD, 2016)

\section{Analisis Nilai Tambah}

Nilai tambah adalah pertambahan nilai suatu komoditas karena adanya perlakuan yang ditambahkan terhadap suatu komoditas (Hayami et al., 1987). Helda (2004) menyatakan bahwa nilai tambah adalah selisih nilai produk dengan biaya bahan baku dan biaya input sedangkan keuntungan adalah selisih nilai tambah dengan pendapatan tenaga kerja langsung (Tabel 4).

Harga bahan baku lateks yaitu Rp 8000/kg. Harga bahan baku ditentukan oleh harga yang berlaku saat itu. Faktor konversi dihitung merupakan pembagian antara nilai output dengan nilai input. Nilai faktor konversi sebesar 1. Tenaga kerja yang dihitung yaitu semua tenaga kerja yang berperan langsung dalam proses produksi pengolahan kasur busa. Koefisien tenaga kerja merupakan hasil bagi antara tenaga kerja dan bahan baku yang digunakan. Nilai koefisien tenaga kerja sebesar 0,006875. Sumbangan input lain terdiri dari bahan penolong, listrik, penyusutan peralatan dan biaya tambahan lainnya yaitu 34655,24 . Input lain juga berupa bahan penunjang dalam proses pembuatan karet busa seperti bahan penvulkasnisasi, pembentuk gel, katalisator dan bahan pengembang seperti amonium oleat (Maspanger, 2007). Nilai output merupakan hasil perkalian dari faktor konversi dan harga output rata-rata. Besar nilai output yaitu 46331,76. Pada metode Bayes, perolehan nilai tambah diperoleh dengan cara mengurangkan nilai output dengan harga bahan baku dan sumbangan input lain. Nilai tambah yaitu sebesar 8549,56 . Dari perhitungan nilai tambah dapat diperoleh rasio nilai tambah yaitu dengan cara membagi nilai tambah dengan nilai output. Rasio nilai tambah merupakan presentase nilai tambah terhadap nilai output. Besar rasio nilai tambah pada adalah $18,45 \%$. Pada karet busa, imbalan tenaga kerja adalah sebesar Rp 5,328125/kg, tingkat keuntungan sebesar $18,45 \%$ dan marjin sebesar Rp 43204,8. Hasil penelitian Hutagalung dkk. (2017) menunjukkan bahwa besarnya nilai tambah setiap proses produksi sheet angin dari lateks adalah sebesar Rp. 1778,00 /kg bahan baku.
Tabel 4. Nilai Tambah Pengolahan lateks pekat menjadi kasur busa

\begin{tabular}{|c|c|c|c|}
\hline No. & $\begin{array}{l}\text { Keluaran (output), } \\
\text { Masukan (Input), dan } \\
\text { Harga }\end{array}$ & & $\begin{array}{l}\text { Kasur Busa } \\
\text { dan Skim } \\
\text { Karet } \\
\end{array}$ \\
\hline 1 & Output/produk total & $A$ & 8000 \\
\hline 2 & Input bahan baku & B & 8000 \\
\hline 3 & Input tenaga kerja & $\mathrm{C}$ & 55 \\
\hline 4 & Faktor konversi & $D=A / B$ & 1 \\
\hline 5 & Koefisien tenaga kerja & $E=C / B$ & 0,006875 \\
\hline 6 & Harga output & $\mathrm{F}$ & 46331,76 \\
\hline \multirow[t]{2}{*}{7} & $\begin{array}{l}\text { Upah rata-rata tenaga } \\
\text { kerja }\end{array}$ & $\mathrm{G}$ & 775 \\
\hline & \multicolumn{3}{|c|}{ Pendapatan dan Keuntungan } \\
\hline 8 & $\begin{array}{l}\text { Harga input bahan } \\
\text { baku }\end{array}$ & $\mathrm{H}$ & 3126,96 \\
\hline 9 & Sumbangan input lain & I & 34655,24 \\
\hline 10 & Nilai output & $J=D F$ & 46331,76 \\
\hline \multirow[t]{2}{*}{11} & a. Nilai tambah & $\mathrm{K}=\mathrm{J}-\mathrm{I}-\mathrm{H}$ & 8549,56 \\
\hline & b. Rasio nilai tambah & $\begin{array}{l}L(\%)=(K / J) \\
100 \%\end{array}$ & 18,45291437 \\
\hline \multirow[t]{2}{*}{12} & a. Imbalan tenaga kerja & $M=E G$ & 5,328125 \\
\hline & b. Bagian tenaga kerja & $\begin{array}{l}N(\%)= \\
(M / K) 100 \%\end{array}$ & 0,062320459 \\
\hline \multirow[t]{3}{*}{13} & a. Keuntungan & $\mathrm{O}=\mathrm{K}-\mathrm{M}$ & 8544,231875 \\
\hline & b. Tingkat keuntungan & $\begin{array}{l}\mathrm{P}(\%)=(\mathrm{O} / \mathrm{J}) \\
100 \%\end{array}$ & 18,44141443 \\
\hline & $\begin{array}{l}\text { Balas jasa untuk } \\
\text { pemilik faktor-faktor } \\
\text { produksi }\end{array}$ & & \\
\hline \multirow[t]{4}{*}{14} & Laba & $\mathrm{Q}=\mathrm{J}-\mathrm{H}$ & 43204,8 \\
\hline & $\begin{array}{l}\text { a. Pendapatan tenaga } \\
\text { kerja }\end{array}$ & $\begin{array}{l}R(\%)=M / Q \\
100 \%\end{array}$ & 0,012332252 \\
\hline & $\begin{array}{l}\text { b. Sumbangan input } \\
\text { lain }\end{array}$ & $\begin{array}{l}S(\%)=1 / Q \\
100 \%\end{array}$ & 80,21155057 \\
\hline & c. Keuntungan usaha & $\begin{array}{l}T(\%)= \\
(O / Q) 100 \%\end{array}$ & 19,77611718 \\
\hline
\end{tabular}

\section{KESIMPULAN}

Berdasarkan hasil perhitungan dengan menggunakan metode Bayes, maka komoditas unggulan dan lokasi terpilih di Provinsi Lampung masing-masing adalah kasur busa dengan nilai sebesar 4,048 dan Kabupaten Lampung Utara dengan nilai 3,875 . Sementara itu, berdasarkan analisa metode Hayami maka nilai tambah yang dihasilkan jika lateks pekat diolah menjadi kasur busa adalah Rp. $8549,56 / \mathrm{kg}$ lateks pekat dengan nilai rasio nilai tambah adalah sebesar $18,45 \%$.

\section{DAFTAR PUSTAKA}

Badan Penelitian Teknologi Karet Bogor. (2002). Modul Kursus Teknologi Barang Jadi latek. Bogor.

Badan Perencanaan Pembangunan Daerah Kabupaten Lampung Utara. (2016). Data Statistik Pembangunan Kabupaten Lampung Utara 2015-2016. Lampung Utara.

bps.go.id. (2019). Diakses dari: https://www.bps.go.id/publication/download.html

Căruntu, C. \& Lăpăduşi, M.L. (2012). Methods used in determining the value added used in the assesment of the company's real cconomic power. Annals of the University of Petroşani, Economics, 12 (1), 33-48. 
Fauzi, I.R. (2013). Alternatif strategi pengembangan industri barang jadi karet di indonesia. Warta Perkaretan, 32(2), 55 - 64. DOI: https://doi.org/10.22302/ppk.wp.v32i2.37

Febriyant., Affandi, M.I.\& Kalsum, U. (2017). Analisis finansial dan nilai tambah agroindustri keripik pisang skala UMK di Kota Metro. Jurnal IImu-ilmu Agribisnis (JIIA), 5 (1), 48-56. DOI: 10.23960/jiia.v5i1.\%25p

Firdaus, N. (2014). Analisis Nilai Tambah Usaha Pemindangan Ikan. Skripsi. Bogor: Fakultas Perikanan dan IImu Kelautan IPB.

Hayami, Y., Kawagoe, T., Morooka, Y \& Siregar, M. (1987). Agriculture marketing and processing in upland Java, $A$ Perpective from a Sunda village, CGPRT No. 8. Bogor: CGPRT Center.

Helda. (2004). Analisis Nilai Tambah Pengolahan Ikan Teri di Pulau Pasaran, Provinsi Lampung. Skripsi. Bogor: Fakultas Perikanan dan IImu Kelautan IPB.

Hutagalung, R.E., Elwamendri \& Fathoni, Z. (2017). Analisis nilai tambah pengolahan lateks menjadi sheet angin di kabupaten Muaro Jambi (Studi kasus pada kelompok tani Sejahtera Bersama desa Muhajirin kecamatan Jambi Luar Kota). Jurnal IImiah SosioEkonomika Bisnis, 20 (2): 2621-1246. DOI: doi.org/10.22437/jiseb.v20i2

Ibrahim, Y.H.M. (2009). Studi Kelayakan Bisnis. Edisi Revisi. Penerbit Rineka Cipta. Jakarta

Kusuma, C., Sutopo, W. \& Hisjam, M. (2016). Value Chain Analysis of Cantula Fiber as a Material of Electric Vehicle Interior, Proceedings - Joint International Conference on Electric Vehicular Technology and Industrial, Mechanical, Electrical and Chemical Engineering, ICEVT 2015 and IMECE 2015. Surakarta: IEEE.

lampung.antaranews.com. (2019). Harga getah karet di lampung. Diakses dari https://lampung.antaranews.com/berita/333351/hargagetah-karet-di-lampung-turun

lampung.bps.go.id. (2019). Diakses dari: https://lampung.bps.go.id/publication/download.html?

Mardiyanto, H. (2013). Analisis pengaruh nilai tambah ekomoni dan nilai tambah pasar terhadap harga saham pada perusahaan sektor ritel yang listing di BEI. Jurnal IImu Manajemen, 1(10), 297-306.

Marimin. (2007). Konsep dan Aplikasi Sistem Pendukung Keputusan. Yogyakarta: Andi Publisher.

Marsongko. (2013). Pembuatan sarung tangan dari lateks alam yang divulkanisasi radiasi dan belerang. Jurnal Kimia Kemasan. 35,131-140. DOI: 10.24817/jkk.v35i2.1885

Maspanger, D.R. (2007). Pembuatan lateks dadih dengan proses sentrifugasi putaran rendah dan kualitas barang jadi karetnya. Agritech, 27 (3),124-129. DOI: 10.22146/agritech.9601

Nurhayati, C.\& Andayani, O. (2012). Teknologi pengolahan lateks cair menjadi karet busa. Jurnal Dinamika Penelitian Industri. 23 (1), 12-20. DOI: 10.28959/jdpi.v23i1.551

Prabowo, H. (2004). Penerapan economic value added untuk memaksimalkan nilai perusahaan: Studi kasus PT XYZ. The Winners, $5(1), 19-33$.

Priyarsono, D.S. (2011). Dari Pertanian ke Industri, Analisis Pembangunan dalam Perspektif Ekonomi Regional. Bogor (ID): IPB Press.

Pujiastuti, L. (2007). Pengaruh Waktu dan Suhu Vulkanisasi pada Pembuatan Kasur dari Serat Sabut Kelapa Berkaret. Skripsi Departemen Teknologi Industri Pertanian. Institut Pertanian Bogor

Purwaningsih. (2015). Analisis nilai tambah prodorabouk perikanan lemuru pelabuhan Muncar Banyuwangi.
Jurnal IImiah Teknik Industri. 14 (1), 13-23. DOI: 10.23917/jiti.v14i1.620

Putri, A.S., Sutopo, S., Prihawantara, S. \& Matheos, R.C.D. (2015). Value chain improvement for cocoa industry in Indonesia by consider input-output analysis. Lecture Notes in Engineering and Computer Science 2, 947952.

Rangkuti, A.H. (2011). Teknik pengambilan keputusan multi kriteria menggunakan metode bayes, MPE, CPI dan AHP. ComTech. 2 (1), 229-238. DOI: 10.21512/comtech.v2i1.2738

Safri, M., Rauf, R.A. \& Howara, D. (2013). Analisis nilai tambah abon sapi pada industri rumah tangga mutiara Hj. Mbok Sri di Kota Palu . J. Agrotekbis. 1 (4), 370-376.

Suliyanto. (2010). Study Kelayakan Bisnis: Pendekatan Praktis. Penerbit Andi. Yogyakarta

Suparto, D. \& Syamsu,Y. (2008). Pengembangan Teknologi Tepat Guna Pembuatan Barang Karet Berbasis Lateks Pravulkanisasi. Bogor: Badan Penelitian Teknologi Karet.

Sutopo, W., Maryanie, D.I., Purwanto,A.\& Nizam, M. (2013), A Comparative Value Chains Analysis of Battery Technologies for Electric Vehicles, Proceedings of the 2013 Joint International Conference on Rural Information and Communication Technology and Electric-Vehicle Technology, rICT and ICEV-T 2013: Denpasar: IEEE.

Sutopo, W., Maryanie, D.I., Purwanto, A.\& Nizam , M. (2014), A comparative value chains analysis of solar electricity for energy. Lecture Notes in Engineering and Computer Science, 2210

Wijaya, I. R.A., Masyhuri, Irham \& Hartono, S. (2014). Analisis input output pengolahan tembakau di Provinsi Jawa Timur. Agro Ekonomi. 24 (1), 1-9. DOI: 10.22146/agroekonomi.17355

Yudopranoto, K. (2006). Perbandingan Populasi Tungau Debu Rumah Pada Kasur Kapuk dan Non Kapuk di Perumahan PJK Kelurahan Randusari Semarang Selatan Jawa Tengah. Universitas Diponegoro. Semarang.

Yuliana. (2007). Kontribusi industri pengolahan hasil perikanan tradisional terhadap pendapatan nelayan pengolah. Jurnal Matematika, Sains, dan Teknologi. 8 (1), 1-10. 
